\title{
COMPARATIVE ANALYSIS OF FORENSIC EXPERT ACTIVITY: AN ADMINISTRATIVE, CRIMINAL, CRIMINALISTIC, ECONOMIC APPROACH
}

\author{
Oleksandr Khrystov' ${ }^{1}$, Vladyslav Lipynskyi²
}

\begin{abstract}
The article is devoted to the economic and legal comparative analysis of judicial expert activities. The issues concerning the problems of quality assurance of the expert activities, harmonization and convergence of the understanding of the possibilities of judicial economic expertise in solving problems of justice, taking into account economic conditions. As a first step to creating a general theoretical development for judicial economic expertise could be the creation of a list of vocabulary of basic terms of forensic economic expertise. The legislation of Ukraine, which regulates activities of forensic experts, is as follows: the Law of Ukraine "On Forensic Examination", "Instruction on Conducting Forensic Examination", "Procedure for Certification and Official Registration of Forensic Examinations Procedure", "Some Issues of Provision of Paid Services by Research Institutions on Forensic Examination of the Ministry of Justice", "On Approval of the Instructions on Procedure and Amount of Reimbursement and Compensation to Individuals Invited by Inquiry Agencies, Pretrial Investigation Agencies, Procuracy, Courts or Authorities that Oversee Cases of Administrative Violations, and Payments to Governmental Research Institutions on Forensic Examination for Expert and Specialized Services Provided by their Employees" approved by the Cabinet of Ministers of Ukraine, and a set of multi-agency orders. The common features include the existence of department specialized forensic expert institutions, which are entrusted to conduct an examination as follows: specialized research institutes of the Ministry of Justice of Ukraine and the Ministry of Healthcare, expert services of the Ministry of Internal Affairs, Security Service of Ukraine, etc. Moreover, forensic examinations, which are often arranged in criminal proceedings and sometimes in administrative proceedings, can be carried out exclusively by forensic experts who are employees of such institutions. At the same time, the law provides for the possibility of carrying out forensic expert activity on a business basis, on the ground of special authorization, as well as onetime agreements, by citizens who have the qualification of a forensic expert, which is often used in administrative proceedings. Neither a judge nor any other persons, who are involved in administrative or criminal procedures, have this kind of expert knowledge. By virtue of the knowledge that is converted by forensic experts in the source of evidence, important issues of a case are resolved that would be impossible without forensic expertise. In legal science, there is an idea that expert activity, due to its specificity, is much wider than expert procedure regardless of the fact whether it is carried out in administrative or criminal procedures.
\end{abstract}

Key words: forensic expert activity, administrative procedures, criminal procedures, law, legislation.

JEL Classification: E44, H10, K10, K13

\section{Introduction}

In the first and second procedures, forensic experts are guided by the same regulatory framework: the Constitution of Ukraine, laws, by-laws, international treaties, etc. For example, in accordance with the Constitution of Ukraine, the principle of the rule of law is recognized and in force. Art. 8 of the Constitution contains the provision that the Constitution of Ukraine has supreme legal force, laws and other regulatory legal

Corresponding author:

${ }^{1}$ Dnipropetrovsk State University of Internal Affairs, Ukraine.

E-mail: alexander hristov@ukr.net

${ }^{2}$ University of Customs and Finance, Ukraine.

E-mail: lipinskivlad@ukr.net acts are adopted on the ground of the Constitution of Ukraine and must comply with it (Verkhovna Rada Ukrainy, 1996). Initiation of legal action to protect the constitutional rights and freedoms of a person and a citizen is directly guaranteed on the basis of the Constitution of Ukraine. In accordance with Art. 9 of the Fundamental Law, the international treaties in force, the consent to their binding is agreed by the Verkhovna Rada of Ukraine, are a part of the national legislation of Ukraine (Verkhovna Rada Ukrainy, 1996). 
M. H. Shcherbakovskyi, in one of his papers, notes that depending on what aspect of the forensic activity an emphasis is laid on, a forensic inquiry is understood as: the institute of evidence and procedural laws; the system of procedural relations; the form of expert knowledge use; the procedure of investigating and drawing up a procedural document upon its completion - an expert report (Shcherbakovskyi, 2008).

The task of administrative procedure is to solve individual administrative cases, which are disputes about the legitimacy of bringing to administrative responsibility, as well as disputes in various branches of legislation such as budget, customs, tax law, etc. Expertise significantly expands the evidence-based possibilities of subjects of administrative and tortious as well as administrative and judicial procedures and also makes it possible to use unlimited opportunities of the modern science during the trial (Romanenko, 2013).

\section{The administrative approach of forensic expert activity}

The Code of Administrative Procedure of Ukraine (hereinafter referred to as the CAPU) doesn't have the definition of the term "forensic expertise," but the terminology has been developed by scholars in research on forensic expertise issues in administrative procedure.

Some scholars define the forensic expertise in the CAPU as a special research of certain actual facts of an administrative case, which is conducted on the basis of decision of administrative court by a special subject (a person), which has expert knowledge in science, art, technology, profession, etc. that leads to the appearance of a new source of evidence - expert conclusion (Dzhafarova, 2013). Others define the forensic expertise in administrative proceeding as one that deals with an issue on the ground of expert knowledge and skills, which occur during a proceeding and judicial examination of administrative cases (Kravchuk, 2016). One of the differences between the expert examinations in administrative and criminal proceedings is that in the first case it is scheduled and carried out less often. The reason for this is the administrative process itself, which concerns the management sphere.

Most often the legal acts, decisions of the subjects of authoritative powers are disputed. Moreover, an expert study is often not binding. In criminal proceedings, six grounds for the mandatory schedule of an expert examination, which are often appointed by a court, investigation bodies or at a request of the defence, are legally determined.

In administrative procedure, an expert examination can be scheduled exclusively by a court (Art. 102 of the CAPU), which decides on the application of a party to a case or suo motu to schedule an expert examination in the case, but it can be also conducted on the request of trial participants (Art. 104 of the CAPU), when a party to a case has the right to present an expert report, which is drawn up on its request, to the court (Verkhovna Rada Ukrainy, 2005). Therefore, Art. 68 of the CAPU defines the expert as a person who has special knowledge necessary to clarify the relevant circumstances of a case (Verkhovna Rada Ukrainy, 2005).

The Code of Ukraine on Administrative Offenses does not provide the definition for an expert. At the same time, the Criminal Procedure Code of Ukraine defines the expert as a person who have scientific, technical or other special knowledge, has the right, in accordance with the Law of Ukraine "On Forensic Examination", to conduct an examination and who is entrusted to investigate objects, phenomena, and processes that contain information about the circumstances of the commission of a criminal offense and to give an opinion on questions arising during criminal proceedings and relating to the sphere of his knowledge (Verkhovna Rada Ukrainy, 2013). The CPC of Ukraine also has restrictions on the possibility to involve persons, as an expert, who have official or other dependence on the parties to criminal proceedings or a victim. So, such persons must announce their recusal on legal grounds.

According to the standards of the CAPU, an expert can be appointed by the court or involved by a participant of a trial. In other words, each party can involve own expert in order to conduct special investigations that is a trusted person whose opinion is a bona fide. But this kind of person can act only for the benefits of the interested party, and due to this fact, there are doubts about his impartiality and reliability of the report. However, this provision is more democratic than in CPC of Ukraine, as Arts. 69 and 243 of CPC (the procedure for expert involvement) indicate that an expert acts by an order which is provided by a court and has impersonal nature. An interested person petitions for investigating judge to carry out an expert examination but such a request doesn't include the surname of a forensic expert, who will carry out an examination.

The rights of experts are other distinction. The CAPU interprets the rights of experts as follows. The expert has the right (Verkhovna Rada Ukrainy, 2005):

- To study case files which are very important, because due to poor actual knowledge about the subject of investigation it will be difficult for an expert, and sometimes it is impossible, to be up to speed on what is a matter of the investigation.

- To submit a petition for additional files and samples, if the examination is scheduled by the court. The expert uses this right in the case when it is impossible to carry out the investigation without particular files.

Paragraphs 3-6 copy the Law of Ukraine "On Forensic Examination" and repeat the right of an expert in criminal procedure as follows:

- To present facts found out in the course of performing the expert examination in the report, which have importance for a case and are beyond doubts in regard to expert initiation that can be limited differently 
in the CPC of Ukraine. The expert in the administrative procedure has more freedom of action in this aspect that permits him to indicate personal comments in the report towards facts, which are not taken into account by the court and which, in his opinion, have importance to solve a case on the merits.

- To be present during performing legal proceedings that concern subject and object of investigation, as well as expert initiation, as an expert upon his own initiative decides it is necessary to carry out a comprehensive and impartial examination to answer questions, which are raised by the court.

- To file a request for interrogation of case's participants and witnesses for the purposes of expert examination performance - an opportunity to realize expert initiation to the full extent, due to which an expert, acting dynamically and crossing the line of formalistic performance of court order, determines the extent of relevant information, which is required for proper implementation of his responsibilities.

- To use other rights provided by the Law of Ukraine "On Expert Examination". These rights can be: to file complaints about the actions of the person in whose proceedings the case is, if these actions violate the rights of a forensic expert, as well as to receive remuneration for conduct of forensic examination, if its performance is not an official task, etc. (Verkhovna Rada Ukrainy, 2005). The legislator has added this provision in order that an expert doesn't cross the line of a neutral party of another participant of a proceeding, standing up for neither the defence nor the prosecution.

\section{Forensic experts on the basis of the Law of Ukraine "On the Protection of Persons Involved in Criminal Proceedings"}

Securing protection is implemented for forensic experts on the basis of the Law of Ukraine "On the Protection of Persons Involved in Criminal Proceedings" (Verkhovna Rada Ukrainy, 1994). The law stipulates the protection of life, health and different, equal to others, kinds of protection for participants of legal proceedings, including the expert participating in proceedings, in order to minimize the impact on him and his professional activities on the part of the interested party. Among the security measures, the law defines as follows as: close protection, housing and property protection; provision of special personal protective equipment and danger notification; use of technical means of control and monitoring of telephone and other negotiations, visual observation; change of documents and appearance; change of place of work or study; resettlement to another place of residence; placement in a preschool educational institution or institution of social protection for the public; confidentiality of personal data; private trial or other measures that would ensure the safety of the participant of court proceedings (Verkhovna Rada Ukrainy, 1994).
During the examination, the expert initiative may be manifested through the selection of the most rational way of conducting the research, as well as violation of the limits of questions, which are raised by the court in order to substantiate new facts that are important for the resolution of criminal or administrative proceedings (Melnik, 2005). There are also differences related to the issue or examination time. The CAPU has a point of the possibility to schedule a forensic examination during the preparation of an administrative case for consideration that is regulated by para. 2 p. 8 of Art. 180 of the CAPU. The schedule of an examination is also among the means of providing evidence (it is indicated in Art. 115 of the CAPU), which is implemented on the basis of an application submitted to the court in full or in part (Verkhovna Rada Ukrainy, 2005).

The CPC of Ukraine in accordance with Art. 93, evidence gathering is carried out by the parties to the criminal proceedings by conducting investigative actions, one of which is the schedule of examination, after the criminal proceedings have been undertaken within the framework of the investigation. The indictment, which is sent to court, includes not only collected evidence of guilty, including the findings of forensic examination but also the amount of expenses for the involvement of an expert (Article 291, para. 2, p. 8). However, this fact does not prevent the examination by a court order during a trial at the request of one of the parties provided by Art. 332 of the CPC of Ukraine. That's a problem if the reports presented as evidence contradict each other, and the interrogation of experts has not eliminated these contradictions, or the ground is the provision of Art. 509 of CPC, according to which there is a need for a psychiatric examination as a result of inadequate conduct of the defendant, although the notion of inadequacy causes doubts as there is no definition of adequacy as such in the literature on procedural issues, and there is no description of the inadequacy criteria and the subjects who assess the adequacy (Verkhovna Rada Ukrainy, 2013).

There are also differences in the subject of inquiry. In administrative proceedings, subjects are documents, actions of entities of authoritative power, public persons, people, vehicles, and in criminal proceedings such objects are anything except legal matters. So, it may be concluded that the range of objects in criminal proceedings is wider, and in administrative proceedings, each object has specific, distinctive properties because it solves managerial issues.

There are differences between the procedural provisions also in relation to the expert's report as evidence. In the administrative procedure, the expert's report is an independent procedural form to verify available evidence and obtain a new one, and the main purpose of the examination is a qualitative assessment of facts by an expert, taking into account the requirements of the law (Yanchuk, 2009). 
Assessment of the expert's conclusion as evidence is stipulated by Art. 108 of the CAPU, according to which the expert's report is accepted by the court together with other evidence and does not have a predetermined force. Generally, the evidence is assessed in accordance with Art. 90 of the CAPU: the court considers the evidence which is provided by the parties, in its internal conviction, on the basis of their direct, comprehensive, complete, and impartial investigation (Verkhovna Rada Ukrainy, 2005). In reference to the expert report, the court evaluates it from the standpoint of belonging, admissibility, authenticity, and sufficiency, in accordance with the general principles of the law of evidence.

The expert report is interpreted as appropriate if it permits to establish or confirm facts under consideration in the proceedings. The examination establishes or denies facts that are the subject of consideration. An assessment of expert's report in a criminal proceeding, in the context of belonging, is determined by the presence of connections and determinations of the facts that are established by him in relation to the subject of ultimate fact or its individual elements. In order to recognize the expert reports reliable, it is necessary that it is based on the results of the study of objects collected in accordance with adherence to the relevant procedural requirements (Honcharenko, 2010).

A forensic examination is considered eligible if it has appropriate procedural form and there are no doubts about its compliance with the current laws, whether particular evidence is a means for the establishment of facts, which are subjected to be proved. Furthermore, the general proof rules are observed, namely, the completeness and accuracy of collected and synthesized information. Recently, proof from the contrary has become popular among scholars. Features of incompetent proof are most often presented in the scientific literature on the issues of evidence of law: they are received with violation of human rights and freedoms, as a result of not clarifying the rights of the parties to the process; violation of restrictions established for certain categories of persons (Syzonenko, 2003).

The evaluation of evidence in criminal proceedings is regulated by Art. 94 of the CPC of Ukraine according to which an investigator, a prosecutor, an investigating judge, a court, on the basis of a comprehensive, complete, and impartial investigation of the circumstances of the criminal proceedings, assess each submitted evidence by internal conviction in relation to belonging, admissibility, authenticity, and the set of evidence collected in terms of sufficiency and interconnection (Verkhovna Rada Ukrainy, 2013), which is in common with the provisions of the CAPU.

Scholars interpret the evaluation of evidence in different ways. A. R. Bielkin defines it as a logical process for the establishment of existence and character of links between evidence and the determination of role, significance, sufficiency, and ways of evidence use in order to ascertain the truth (Belkin, 1999). Ye. $\mathrm{H}$. Kovalenko determines the evaluation of evidence as the mental activity of a person (investigating officer, investigator, prosecutor, judge) which is aimed at examining facts to establish the truth in the case and which is carried out in certain logical forms in accordance with the law and legal consciousness to their beliefs, based on a comprehensive, complete, and impartial analysis of all circumstances of the case in aggregate. It is also aimed at establishing the authenticity and belonging, admissibility and sufficiency of the evidence, their relationship and significance for solving issues that constitute the ultimate fact (Kovalenko, 2011). This definition is quite exact as it fully reflects the content of proof and dealing with the evidence of relevant actors.

Scholar-criminalists note that the expert opinion assessment is carried out in the criminal procedural dimension both as formal and as content one. The formal assessment consists in verifying the correspondence of the number of raised questions, their compliance with the procedure, the sufficiency of materials provided for the study, the content of the proceedings used by the expert to formulate a conclusion. In turn, the content evaluation includes analysis of methods, tools, and techniques of investigation, completeness and validity of the investigation, correctness, logic and the absence of contradictions (Varfolomeieva, Honcharenko, Boiarov, Honcharenko, Popeliushko, 2011).

Another scientific position is connected with the fact that the expert's opinion may be evaluated by the initiator of the schedule of an expert study, and in addition all those who are familiar with the materials of criminal proceedings, while statements, petitions, and protests concerning an expert opinion contribute to the establishment of the truth in the proceedings (Markus, 2007).

If we compare this provision with administrative proceedings, there is a significant difference when familiarizing with the expert's conclusion of the parties. If the forensic examination was conducted before the trial began, then as a proof, it together with a copy of the statement of claim is presented to the other party, and all comments on it are not left too late before the final decision is made. That is, the other party is given time to express its opinion about the provided evidence, to challenge it or to agree with it.

In addition to the above-mentioned differences, it is also possible to specify forensic examinations in these two procedures. If the legislator determines the obligatory types of forensic examinations in Art. 242 of the CPC of Ukraine, they are as follows: determining the causes of death - forensic examination of the corpse is applied; determining definite bodily injury - forensic medical examination of the degree of bodily injuries - living persons, as well as forensic examination of the mechanism of infliction of bodily harm; determining the mental condition of a suspected person - forensic psychiatric examination - outpatient 
or in hospital depending on the fact whether such person was registered with a psychiatrist; when determining the age of a person - forensic medical examination of living persons, as well as psychological examination; establishing the sexual maturity of a victim - forensic medical examination; determining the amount of tangible damage - commodity examination (Verkhovna Rada Ukrainy, 2013).

The types of examinations in the administrative procedure are determined more complex. Among certain types of expert examinations in the administrative procedure are forensic-economic, construction and technical, fire and technical, handwriting, forensic, medical and social, commodity, the examination of land evaluation, art examinations, etc. The Unified State Register of Judicial Decisions denotes an annual increase of the number of performed forensic examinations in the administrative proceedings. The forensic economic examination is among the leaders in administrative procedure, which is a form of implementation of finance and economic control, and it is also very important to justify the reliance of managerial decisions that are adopted by enterprises (Perevozova, 2013).

Economic examination is defined by scholars as the study of certain problems that arise in the process of economic activity of the entity and require qualified actions of expert (experts) to achieve a specific goal and to solve peculiar tasks related to financial and tax accounting, financial and economic activity and finance and credit operations, as well as to prevent significant threats and risks from this kind of subject (Derii, Dema, 2017). We believe that we should agree with this definition.

Legal examination is important for administrative procedure as it related to the establishment of compliance with the current legislation, purpose and means, certain mechanism for the implementation of act being appealed, the list of documents submitted for the relevant actions, as well as the sufficiency of subject powers for their execution (Kalmykova, 2013).

Among the new types of forensic examinations in administrative procedure, it is also determined psychological examination, which becomes more widespread. It can act as proof of the following: whether a certain person can be a subject of an administrative infraction, what is the form of his guilt and which motives of behaviour were fundamental. In most cases, a psychological examination is carried out during administrative proceedings, and the information which is subjected to be analysed by an expert contains testimonies of offenders, witnesses, victims to the circumstances of committed actions. A psychological examination is carried out in several stages. At the first stage, experts investigate the available evidence, in future, they can apply for the submission of documents, which would more fully characterize the personality of the examinee, than an experimental psychological investigation is carried out and, based on its results, the expert opinion is formed, which is announced in court. It is difficult to solve issues with several examinees: it is not clear how to conduct the study - either simultaneously or sequentially (Kostytskyi, 2013).

In accordance with the current legislation, as well as any other evidence, the court evaluates the examination on the basis of inner convictions, in concordance with case files. As a special feature of administrative proceedings in the schedule and execution of forensic examinations, it is necessary to mention the division of examinations into additional, repeated, commission and complex (Arts. 9-11 of the CAPU), which exists also in criminal procedural law, but procedural requirements for which are not indicated at the legislative level, in the CPC of Ukraine.

Particular attention should be given to novels associated with amendments to the CAPU, which cover issues of legal regulation of court costs in administrative proceedings. Thus, the articles of the CAPU determine the types of court costs, the procedure and terms of their reimbursement, disposition of funds, etc. Art. 132 of the CAPU states that the court costs consist of court fees and expenses related to the consideration of a case. The amount of court fee, the procedure for its payment, reimbursement, and fee waiver shall be consolidated by law. Costs related to the case consideration are expenses: on professional legal assistance; of parties and their representatives connected with their arrival at the court; associated with the involvement of witnesses, specialists, translators, experts and expert examinations; related to the disclosure of evidence, the examination of evidence over their location, the provision of evidence; connected with other procedural actions or preparation for consideration of the case (Verkhovna Rada Ukrainy, 2005).

When scheduling an expert examination or involving an expert, the law provides advance payment of legal expenses. Thus, the court may oblige the participant, who filed an application for the schedule of an expert examination, the involvement of an expert, provision, disclosure or study of evidence at their location, advance (in advance), to cover the costs associated with a particular procedural act. If several parties have filed a motion, the necessary amount of money shall be paid, in equal shares, by relevant participants of the case in advance, and in cases where the relevant procedural action is carried out on the initiative of the court - by the participant (participants) of the case, who is obliged by the court (Art. 136 of the CAPU) (Verkhovna Rada Ukrainy, 2005).

The article also specifies the consequences of late payment of court costs - in the case of non-payment of particular sums in advance in term specified by court, a court can reject the request for schedule of examination, involvement of an expert, provision, disclosure or study of evidence at their location and make a decision on the basis of other evidence provided by the case 
participants or cancel the previously approved decision on the schedule of an expert examination, the provision, disclosure or study of evidence at their location. A court reviewing the merits of the case may redistribute the expenses, specified in this article, paid by the party to the case in advance, in accordance with the rules on distribution of court costs established by this Code (Verkhovna Rada Ukrainy, 2005).

Article 137 of the CAPU determines the volume of expenses related to the involvement of experts and performing expert examinations, the procedure for their payment, and the consequences of late payment. Thus, an expert receives a reward for executed activities (rendered services) related to the case, if it is not a part of his official duties. In cases where the amount of expenses for the work (services) of an expert or performance of expert examination was not previously paid by the participants of the case (in advance), the court recovers these amounts in favour of an expert or expert institution from a party, which is determined by the court in accordance with the rules on the apportionment of court costs that are consolidated by this Code.

It is determined at the legislative level that expenses for the preparation of an expert report upon the request of a party, carrying out an examination, the involvement of an expert is established by the court on the basis of contracts, accounts, and other evidence. However, it should be noted that the form, structure, and content of these contracts and accounts remain the gap. The definition of the requirements in the article regarding the balance of costs with complexity, extent of work, and time for its implementation, which states that the volume of expenses for the payment of works (services) of the expert involved by a party must commensurate with the complexity of work (services), its volume and time spent to perform work (services) doesn't not eliminate gaps, as well as the following provisions of this article: in case of non-compliance with the requirements for commensurability of expenses, the court may, at the request of the other party, reduce the volume of costs for the payment of works (services) of a specialist, translator or expert, which are subjected to the distribution between the parties; obligation to prove the incommensurability of costs is laid upon the party claiming a reduction in costs, which are is subject to be distributed between the parties (Verkhovna Rada Ukrainy, 2005).

According to para. 9 of Art. 139 of the CAPU in deciding on the distribution of court costs, the court takes into account: whether these expenses are connected with consideration of a case; whether the volume of these costs is reasonable and proportional to the subject of a dispute, case significance for the parties, including whether the result of the case solution may influence the image of a party or whether a case sparkles a public interest; party's behaviour during conducting a trial that leads to delaying of case consideration, in particular, submission of clearly unfounded claims and requests by a party, fact-free assertion or denial of certain facts by the party, which are important for the case, etc.; actions of a party in relation to the pre-trial settlement of a dispute (in cases where pre-trial dispute resolution is mandatory according to the law) and the dispute settlement by peaceful means during the consideration of a case, the stage of case consideration in which such actions were performed (Verkhovna Rada Ukrainy, 2005).

The requirements for the amount of expenses, which a party has paid or should pay in connection with the consideration of the case, is established by the court on the basis of evidence provided by the parties (contracts, accounts, etc.), as the regulation of Art. 139 of the CAPU indicates. It is also noted that such evidence is submitted before the end of legal debate in the case or within five days after approval of court decision if a party has made a corresponding application before the end of the court debate in the case. In the context of the lack of a relevant application or failure to submit appropriate evidence within the deadline, the application remains unconsidered.

The peculiarities of the decision on court costs are noted in Art. 143 of the CAPU, which states that a court resolves the issue on court costs in a decision, ruling or order. At the same time, participants of a case, witnesses, experts, specialists, and interpreters may appeal a court decision on costs, if it concerns their interests. However, if a party, for good reason, cannot submit evidence that verify the amount of legal expenses incurred by it, the court may, on the basis of application of such a party submitted before the end of legal debates in the case, decide the issue of legal costs after the decision for essence of complaints.

A specific feature is that, in order to resolve the issue of court costs, the court appoints a court session, which is held not later than fifteen days from the day of the decision on the merits of the claims, or makes an additional decision if a party cannot, for good reason, submit proofs of the amount of legal expenses incurred by it until the end of legal debate. In the case of adoption of a decision on termination of proceedings on the case, keeping a claim without consideration or approval of the decision on the claim satisfaction in connection with its acknowledgment, the court decides on the distribution of court costs not later than ten days from the day of the adoption of relevant court decision, if a party to a case provided an appropriate application and evidence verifying the amount of court costs (Petrova, Shulzhenko, 2018).

\section{Conclusions}

The specific nature of forensic examination in this area is related to a range of issues that are solved by administrative proceedings - from the consideration of misconduct to public-law disputes with the subjects of authoritative power. The CAPU does not provide the term "forensic examination" but, on the basis of above mentioned, it is clear that forensic examination in the 
administrative procedure involves the use of special knowledge while the proceedings, during which there is a new source of evidence - the expert's opinion.

Comparing forensic expert activity that takes place in administrative procedure with the same one in criminal procedure, it is necessary to note a significant difference not only in the execution of procedural provisions of the appointment and conducting of forensic examinations, evaluation of expert's opinion but also in the diversity of issues that are investigated by experts. Of course, administrative proceedings differ from criminal ones but the main details related to forensic expert activity should be reduced to one standard in order to improve the regulatory framework that determines procedural activity.

\section{References:}

Shcherbakovskyi, M. H. (2008). Sudova ekspertolohiia: navchalnyi posibnyk [Forensic expertology: a textbook]. Kharkiv: KNUIA. (in Ukrainian)

Verkhovna Rada Ukrainy (1996). Konstytutsiia Ukrainy: Zakon Ukrainy vid 28 chervnia 1996 r. № 254k/96-VR (zi zminamy ta dopovnenniamy) [The Constitution of Ukraine: the Law of Ukraine dated June 26, 1996 № 254к/96-BP (as amended)]. Vidomosti Verkhovnoi Rady Ukrainy, no. 30, art. 141.

Romanenko, L. M. (2013). Ekspertyza v administratyvnomu protsesi [Expert examination in administrative process] (PhD Thesis). Kyiv: State Scientific Research Institute of MIA.

Dzhafarova, M. V. (2013). Okremi vydy ekspertyz v administratyvnomu sudochynstvi Ukrainy [Individual types of expert examinations in administrative legal proceedings of Ukraine]. Pravo i bezpeka, 1(48), 57-61.

Kravchuk, T. O. (2016). Otsinka vysnovku eksperta ta yoho dokazove znachennia v administratyvnomu sudochynstvi Ukrainy [Assessment of expert report and its eveidentiary value in administrative legal proceedings of Ukraine]. Innovative solutions in modern science, 6(6). Retrieved from: http://naukajournal.org/index.php/ ISMSD/article/viewFile/923/1063

Verkhovna Rada Ukrainy (2005). Kodeks administratyvnoho sudochynstva Ukrainy: Zakon Ukrainy vid 6 lypnia 2005 r. № 2747-IV (zi zminamy ta dopovnenniamy) [Code of Administrative Procedure of Ukraine: the Law of Ukraine dated July 6, 2005 № 2747-IV (as amended)]. Vidomosti Verkhovnoi Rady Ukrainy, no. 35-37, art. 446.

Verkhovna Rada Ukrainy (2013). Kryminalnyi protsesualnyi kodeks Ukrainy: Zakon Ukrainy vid 13 kvitnia 2012 r. № 4651-VI (zi zminamy ta dopovnenniamy) [Criminal Procedure Code of Ukraine: the Law of Ukraine dated April 13, 2012 № 4651-VI (as amended)]. Vidomosti Verkhovnoi Rady Ukrainy, no. 9-13, art. 88.

Verkhovna Rada Ukrainy (1994). Pro zabezpechennia bezpeky osib, yaki berut uchast u kryminalnomu sudochynstvi: Zakon Ukrainy vid 23 hrudnia 1993 r. № 3782-XII (zi zminamy ta dopovnenniamy) [On Protection of Persons Involved in Criminal Proceedings: the Law of Ukraine dated December 23, 1993 № 3782-XII (as amended)]. Vidomosti Verkhovnoi Rady Ukrainy, no. 11, art. 51.

Melnik, S. L. (2005). Aktualnye voprosy ekspertnoj iniciativy [Topical issues of expert initiative] (PhD Thesis). Chelyabinsk.

Yanchuk, O. Iu. (2009). Sudova ekspertyza v administratyvnomu sudochynstvi [Forensic examination in administrative legal proceedings]. Visnyk Akademii advokatury Ukrainy, 2(15), 145-150.

Honcharenko, V. H. (2010). Ekspertyzy u sudovii praktytsi [Forensic examinations in judicial practice]. Kyiv: Yurinkom Inter. (in Ukrainian)

Syzonenko, A. S. (2003). Nedopustymist dokaziv u kryminalnomu sudochynstvi [Inadmissibility of evidence in criminal proceedings]. Visnyk Verkhovnoho Sudu Ukrainy, 5(39), 57-59.

Belkin, A. R. (1999). Teoriya dokazyvaniya [Evidence theory]. Moscow: Norma. (in Russian)

Kovalenko, Ye. H. (2011). Naukovi zasady kryminalno-protsesualnoho dokazuvannia: monohrafiia [Scientific fundamentals of criminal procedure proving: a monograph]. Kyiv: Yurinkom Inter.

Varfolomeieva, T. V., Honcharenko, V. H., Boiarov, V. I., Honcharenko, S. V., Popeliushko, V. O. (2011). Kryminalistyka. Akademichnyi kurs: pidruchnyk [Criminalistics. Academic course: a textbook]. Kyiv: Yurinkom Inter. (in Ukrainian) Markus, V. O. (2007). Kryminalistyka: navchalnyi posibnyk [Criminalistic: a textbook]. Kyiv: Kondor.

Perevozova, I. V. (2013). Nominatyvne pole kontseptu «ekonomichna ekspertyza» v suchasnykh umovakh yoho zastosuvannia $\mathrm{v}$ protsesi zdiisnennia finansovoho kontroliu [Nominative scope of the concept "economic expert analysis" under the modern conditions of its application in the process of finance controlling]. Ekonomika: realii chasu, 2, 150-156. Retrieved from: http://nbuv.gov.ua/UJRN/econrch_2013_2_22

Derii, V. A., Dema, D. I. (2017). Ekonomichna ekspertyza diialnosti pidpryiemstv [Economic expert analysis of enterprises performance]. Ekonomika i suspilstvo, 11, 508-514.

Kalmykova, Ya. S. (2013). Dokazy i dokazuvannia v administratyvnomu sudochynstvi [Evidence and proving in administrative proceedings] (PhD Thesis). Kharkiv.

Kostytskyi, M. V. (2013). Osoblyvosti provedennia sudovo-psykholohichnoi ekspertyzy v administratyvnomu protsesi [Peculiarities of the implementation of psychological expertise in administrative procedure]. Naukovoinformatsiinyi visnyk Ivano-Frankivskoho universytetu prava imeni Korolia Danyla Halytskoho. Seriia «Pravo», 8, 10-16.

Petrova, I. A., Shulzhenko, A. V. (2018). Similarities and differences of forensic expert activity in administrative and criminal procedures. Administrative law and administrative-procedural law: origins, achievements and prospects of development: Collective monograph. Riga: Izdevnieciba «Baltija Publishing». 